\title{
Sensorimotor polyneuropathy as an initial clinical manifestation of sarcoidosis
}

\section{Polineuropatia czuciowo-ruchowa jako początkowy objaw sarkoidozy}

\author{
Waldemar Brola², Renata Pejas-Dulewicz², Jarosław Wasiński³, Jolanta Paszkiewicz ${ }^{4}$, Małgorzata Fudala ${ }^{1}$ \\ ${ }^{1}$ Department of Neurology, Specialist Hospital, Konskie, Poland \\ Head of Department: Waldemar Brola MD, PhD \\ 2Department of Internal Diseases, Specialist Hospital, Konskie, Poland \\ Head of Department: Janusz Karpeta MD \\ ${ }^{3}$ Department of Neurology, Provincial Polyclinical Hospital, Kielce, Poland \\ Head of Department: Ewa Kołodziejska MD, PhD \\ ${ }^{4}$ Department of Pulmonology, Provincial Specialist Hospital, Czerwona Góra, Poland \\ Head of Department: Jolanta Paszkiewicz MD
}

Key words: diagnosis, sensorimotor polyneuropathy, neurosarcoidosis.

Słowa kluczowe: diagnostyka, polineuropatia czuciowo-ruchowa, neurosarkoidoza.

\begin{abstract}
Sarcoidosis is a multi-organ granulomatous disease of unknown aetiology, most frequently affecting the respiratory system. It usually involves lungs and hilar lymph nodes. Pulmonary symptoms can also be accompanied by lesions located in other organs. Although the nervous system is rarely affected, the neurological symptoms can precede the diagnosis of neurosarcoidosis by several years. In this report we present a case of a 24 -year-old male, who reported to his general practitioner due to numbness and hypoaesthesia of distal regions of his upper and lower limbs. Electrophysiological study revealed symmetrical sensorimotor polyneuropathy. Despite the lack of any other symptoms, supplementing the diagnostic evaluation with lung imaging and histopathological examination of bronchial mucous membrane led to the diagnosis of neurosarcoidosis.
\end{abstract}

\section{Streszczenie}

Sarkoidoza jest wielonarządową chorobą ziarniniakową o nieznanej etiologii, z predyspozycją do zajmowania głównie układu oddechowego. Przebiega najczęściej z zajęciem płuc i węzłów chłonnych wnęk. Objawom płucnym mogą towarzyszyć również zmiany w wielu innych narządach. Układ nerwowy zajęty jest rzadko, jednak objawy neurologiczne mogą nawet na kilka lat wyprzedzać rozpoznanie neurosarkoidozy. W pracy przedstawiono przypadek 24-letniego mężczyzny, który zgłosił się do lekarza z powodu drętwienia i osłabienia czucia w zakresie dystalnych odcinków kończyn górnych i dolnych. Na podstawie badań elektrofizjologicznych rozpoznano symetryczną polineuropatię czuciowo-ruchową. Mimo braku innych objawów, rozszerzenie diagnostyki o badania obrazowe płuc i badanie histopatologiczne błony śluzowej oskrzela pozwoliło rozpoznać neurosarkoidozę.

\section{Introduction}

Sarcoidosis is a generalised inflammatory disease of unknown aetiology, characterised by the formation of noncaseating granulomas in the lesions. The prevalence of sarcoidosis in Poland is estimated at 7-10/ 100000 people. In most cases the disease involves the lungs, hilar - and mediastinal lymph nodes. It can also be located in other organs of the body, including the ones of the nervous system [1]. Even though the changes in the nervous system are found in only $5-15 \%$ of patients, the neurological symptoms can sometimes be the first ones to be observed, preceding the diagnosis of the systemic disease [2, 3]. In only $1 \%$ of cases, sarcoidosis is limited to just the nervous system. Diagnosing neurosarcoidosis can then be truly problematic.

\section{Case report}

A 24-year-old male patient was admitted to the Department of Neurology due to a tingling sensation in his feet and, though less intensively, his hands, accompanied by muscular weakness in the legs. The symptoms had sustained for several months. Apart from that, there were no other complaints. The neurological examination revealed weakened muscular power of plantar and dorsal flexors in both feet with mild 
atrophy of calf muscles, weakened superficial sensibility in both forearms and lower halves of shanks, trace deep reflexes in the upper limbs and no reflexes in the legs. Medical history did not reveal exposure to exogenous intoxication, the patient did not have any infections during the previous year and there was no family history of hereditary diseases.

Also, no abnormalities were detected on laboratory tests (complete blood count, liver function test, renal function test, glucose, sodium, potassium, total calcium and ionised calcium concentration, general urinalysis, coagulation test including international normalised ratio (INR), activated partial thromboplastin time (APTT), fibrinogen, cholinesterase, creatine phosphokinase (CPK), alkaline phosphatase, lactate dehydrogenase, $\gamma$-glutamyl transpeptidase, total protein, lipid profile, vitamin $B_{12}$ level and thyroid hormones).

Tests of the cerebrospinal fluid (CSF) were performed as well. General examination revealed colourless and fully transparent fluid - cytosis: $132 \mathrm{l} / \mathrm{mm}^{3}$; protein: $1.5 \mathrm{~g} / \mathrm{l}$; glucose: $1.54 \mathrm{mmol} / \mathrm{l}$; and chlorides: $124 \mathrm{mmol} / \mathrm{l}$. Non-characteristic oligoclonal bands were detected. Cytological test revealed the presence of relatively numerous lymphocytes. The presence of anti-Borrellia burgdorferi immunoglobulin M (IgM) and immunoglobulin G (IgG) antibodies was checked with the ELISA test, which gave a negative result.

Abdominal ultrasonography: homogeneous, normoechogenic liver. Thin-walled gallbladder with no evidence of pathology. Non-dilated bile ducts. Homogeneous pancreas of normal size. Homogeneous spleen of normal size (120 mm long). Kidneys of normal size and location with no deposits and no evidence of retention. No evidence of free fluid in the peritoneal cavity. Smooth urinary bladder walls.

Nerve conduction study (NCS): conduction delay in the motor fibre of the median and ulnar nerve and decrease of the response amplitude. F-wave of de-

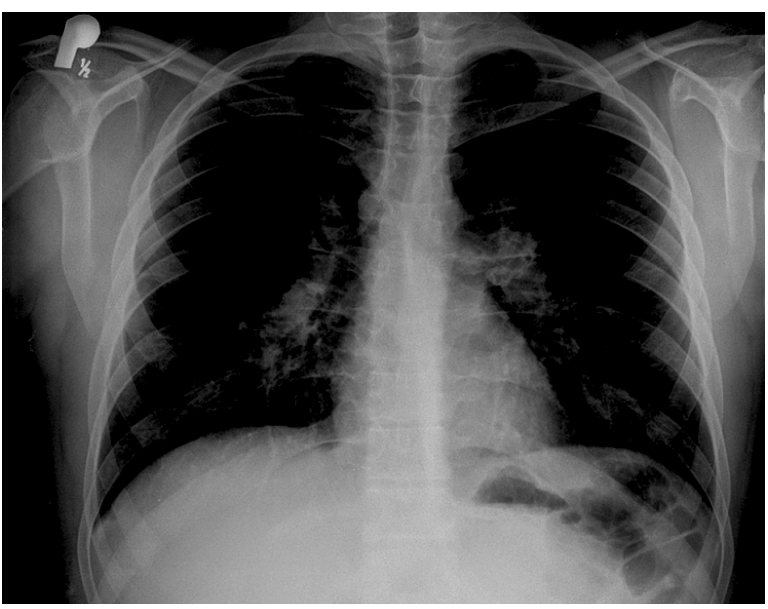

Figure 1. Chest X-ray: hilar enlargement by lymph nodes creased frequency. No conduction in the fibular and tibial nerves in motor fibres. A decrease of response amplitude with conduction delay in the sensory fibres of the ulnar and the sural nerve.

A diagnosis of symmetric sensorimotor polyneuropathy of unknown aetiology was established, which required further diagnostic evaluation.

Routine chest X-ray revealed massive spread of the pulmonary hilar shadow by the enlarged lymph nodes (Figure 1). The patient did not have any complaints; he showed cardiovascular and respiratory stability, denied having any cough, dyspnoea or weight loss. Up to that date, he had been healthy and non-smoking. Physical examination did not reveal any auscultatory abnormalities.

Due to the changes in the X-ray, a suspicion of sarcoidosis was raised and the diagnostic evaluation was extended by chest computed tomography (CT): numerous enlarged lymph nodes located in the upper mediastinum (bilaterally, in the pretracheal area, up to the tracheal bifurcation and next to the aortic arch) and in the hila of both lungs were detected. Band-like reticular interstitial concentrations with micronodular concentrations of 2-5 $\mathrm{mm}$ in diameter were found in both lungs. The picture suggested sarcoidosis (Figure 2).

The patient did not give consent for lymph node or nerve specimen collection for histopathological evaluation. Further additional tests were carried out in search of sarcoidosis symptoms in the organs.

Bronchofiberscopy: hyperaemia of the larynx, trachea and the main carina. Dilated main carina. Right and left bronchial tree: congested and smoothened inflammatorily mucous membrane. Dilation of the submucosal vascular bed. The bronchi that were accessible during the examination were non-obstructed and were moving normally during respiration. Samples of bronchial mucous membrane were drawn for histopathological examination from the fourth right bronchial segment. The examination revealed the

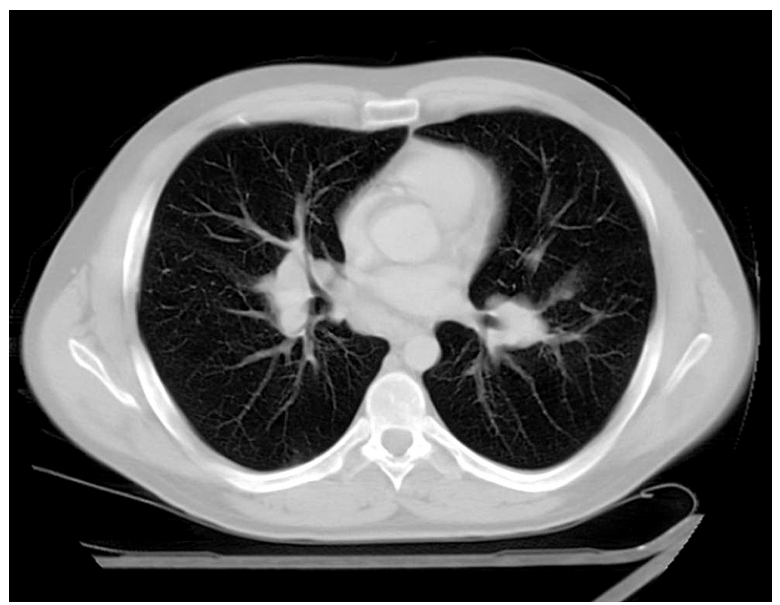

Figure 2. Chest CT scan: enlarged lymph nodes of pulmonary hilum and small nodules in parenchyma of lung 
presence of non-caseating granulomas consisting of epithelial and multinuclear cells, loosely arranged bands of bronchial epithelium and a fragment of aerated pulmonary parenchyma. There was no evidence of fibrosis or focal lesions; single macrophages in the lumen of the alveoli.

Culture of bronchial washings: no pathogenic bacteria were detected. Mycological tests revealed no yeast-like or mould fungi. Cytological test (bronchial washings): numerous bronchial epithelial cells and macrophages, single polynuclear granulocytes, scarce inflammatory cells.

Tuberculin reaction: $(2 \mathrm{u})-12 \mathrm{~mm}$. Spirometry: $\mathrm{FEV}_{1}-98 \%$, VC - 97\%, $\mathrm{FEV}_{1} \% \mathrm{VC}-98 \%$. Spirometric examination and bronchial flow: normal. Gasometry: $\mathrm{pH}$ 7.43, $\mathrm{pO}_{2} 61 \mathrm{~mm} \mathrm{Hg}, \mathrm{pCO}_{2} 35.4 \mathrm{~mm} \mathrm{Hg}$, $\mathrm{HCO}_{3} 23 \mathrm{mmol} / \mathrm{l}, \mathrm{BE}=0.7 \mathrm{mmol} / \mathrm{l}$, Sat. $\mathrm{O}_{2} 91.9 \%$.

Normal ECG, Holter monitor - sinus rhythm: max. 154/min, min. 47/min, mean $95 / \mathrm{min}$. No ventricular ectopy. No pauses. Echocardiogram: Normal size of cardiac cavities. Slightly thickened muscle of the left ventricle. Normal valves. Poorly saturated cusp of the anterior mitral valve. Normal parameters of the diastolic function of the left ventricle. Pericardium with no evidence of fluid.

Ophthalmological consultation: VODS $=1.0$. Normal anterior segment of the eye. The iris had no abnormalities characteristic for sarcoidosis. Normal fundus of the eye.

Based on the suspicion of neurosarcoidosis, the level of angiotensin convertase enzyme (ACE) in serum was measured ( $15 \mathrm{mU} / \mathrm{ml}$; reference range $12-35.9 \mathrm{mU} / \mathrm{ml}$ ).

Sarcoidosis with peripheral nervous system involvement was diagnosed based on the clinical picture and additional tests including the histopathological examination of the bronchial mucous membrane. The patient was then treated with corticosteroids (prednisone at a max. daily dosage of $40 \mathrm{mg}$ ). During several consecutive months a significant decrease of complaints and gradual elimination of limb weakness and hypaesthesia were observed. The patient remains under constant neurological and pulmonological care. He does not have any respiratory complaints. Follow-up examinations conducted in the Pulmonary Clinic showed no evidence of disease progression or involvement of other organs. Currently, the patient is not taking any medication.

\section{Discussion}

Symmetric sensorimotor polyneuropathy can be genetically conditioned, concurrent with many diseases (for example: diabetes; uraemia; nutritional deficiency or disturbances in vitamin $\mathrm{B}_{12}$ absorption; collagen diseases; some infectious diseases; exogenous intoxications with lead, arsenic, thallium; and neoplastic disease), or a post-treatment complication (isoniazid, nitrofurantoin, cytostatic agents). Diagnosis of polyneuropathy is relatively simple if it is concurrent with already-diagnosed systemic diseases. However, if there are no other symptoms of the disease, diagnosing polyneuropathy can be truly problematic.

In approx. $2-3 \%$ of patients the course of sarcoidosis involves damage of the peripheral nervous system, which can have the form of a mononeuropathy, multiple mononeuropathy, or sensory/motor/sensorimotor symmetric polyneuropathy, all being acute (similar to Guillain-Barré syndrome) or chronic progressive [2-4]. Mononeuropathies of the ulnar and fibular nerve are relatively frequent $[3,5]$. It is presupposed that the mechanism of the damage includes inflammatory, vascular and perivascular lesions, as well as fibre compression caused by the nodules [2-4]. Nerve biopsy shows sarcoid granulomas in the epineurial, perineurial and endoneurial spaces, periangiitis, axonal degeneration and segmental fibre demyelination $[5,6]$. Electrophysiological examinations showed features of axonal degeneration or, less frequently, axonal demyelination degeneration [7].

Symmetric polyneuropathy occurs most frequently several months or years after the onset of the disease $[6,8]$. In rare cases, neuropathy can be the first symptom preceding the diagnosis of sarcoidosis. In such cases, just as in the case of isolated sarcoidosis of the nervous system, establishing the diagnosis is difficult.

Neurosarcoidosis can manifest itself in symptoms characteristic for many other chronic, episodic or remitting diseases of the nervous system [3, 4, 9]. The diagnosis of neurosarcoidosis is mainly based on the clinical signs and histopathological examination confirming the presence of non-caseating granulomas in the nervous tissue [10]. It is always crucial to look for other especially pulmonary - symptoms of sarcoidosis. Chest X-ray and CT are first-line examinations, which, in the case described in this paper, directed the differential diagnostic evaluation toward sarcoidosis. Extending the diagnostic evaluation by bronchofiberoscopy and drawing a sample of bronchial mucous membrane allowed us to establish the final diagnosis. The histopathological evaluation of the bronchial mucous membrane and the presence of non-caseating granulomas consisting of epithelial and multinuclear cells proved to be crucial in the diagnostic process, since the patient did not give his consent for nerve or lymph-node biopsy.

Examination of the cerebrospinal fluid can also prove useful in the diagnosis of neurosarcoidosis. Changes in the CSF are not specific and include increased cytosis, increased protein concentration and, sometimes, slightly increased glucose concentration. Moreover, in some patients tests may reveal oligoclonal bands, intrathecal IgG synthesis or increased concentration of the angiotensin-converting enzyme [2]. In the presented case we also found pleocytosis, in- 
creased protein level and oligoclonal bands. However, these aberrations of the norm did not contribute to a definite diagnosis. Nevertheless, the cerebrospinal fluid should always be examined while diagnosing polyneuropathy, since detecting inflammatory condition in the CNS can direct the differential diagnostic process toward systemic diseases [4]. Neural conduction examination is not sufficiently specific, but its result can confirm nervous system involvement and thus confirm the diagnosis.

\section{Conclusions}

Similarly to other systemic inflammatory diseases, neurosarcoidosis should be taken into account in cases of polyneuropathy of unclear aetiology. The only examination that allows for certain diagnosis of neurosarcoidosis is biopsy of the nervous tissue, lymph node tissue or bronchial mucous membrane, with the histopathological examination revealing non-caseating granulomas. Cerebrospinal fluid examination, which can reveal inflammation of the central nervous system, is a useful diagnostic tool in the diagnosis of neurosarcoidosis.

\section{References}

1. Valeyre D, Prasse A, Nunes H, et al. Sarcoidosis. Lancet 2014; 383: 1155-67.

2. Hoyle JC, Jablonski C, Newton HB. Neurosarcoidosis: clinical review of a disorder with challenging inpatient presentations and diagnostic considerations. Neurohospitalist 2014; 4: 94-101.

3. Krumholz A, Stern BJ. Neurologic manifestations of sarcoidosis. Handb Clin Neurol 2014; 119: 305-33.

4. Segal BM. Neurosarcoidosis: diagnostic approaches and therapeutic strategies. Curr Opin Neurol 2013; 26: 307-13.

5. Vital A, Lagueny A, Ferre X, et al. Sarcoid neuropathy: clinico-pathological study of 4 new cases and review of the literature. Clin Neuropathol 2008; 27: 96-105.

6. Said G. Sarcoidosis of the peripheral nervous system. Handb Clin Neurol 2013; 115: 485-95.

7. Challenor YB, Felton CP, Brust JC. Peripheral nerve involvement in sarcoidosis: an electrodiagnostic study. J Neurol Neurosurg Psychiatry 1984; 47: 1219-22.

8. Nemni R, Galassi G, Cohen M, et al. Symmetric sarcoid polyneuropathy: analysis of a sural nerve biopsy. Neurology 1981; 31: 1217-23.

9. Uzawa A, Kojima S, Yonezu T, Kanesaka T. Truncal polyradiculopathy due to sarcoidosis. J Neurol Sci 2009; 281: 108-9.

10. Borratyńska A, Zwolińska G, Turaj W, et al. Neurosarkoidoza i ból. Neur Neurochir Pol 2008; 42: 69-74.

\section{Address for correspondence:}

Waldemar Brola MD, PhD

Department of Neurology

Specialist Hospital

ul. Gimnazjalna 41 B, 26-200 Końskie, Poland

Phone: +48 4139022 59, +48 601313415

Fax: +48 413902364

E-mail: wbrola@wp.pl 